\title{
TGF- $\beta$ signaling blockade inhibits PTHrP secretion by breast cancer cells and bone metastases development
}

\author{
Juan Juan Yin, ${ }^{1}$ Katri Selander,${ }^{1}$ John M. Chirgwin, ${ }^{1}$ Mark Dallas, ${ }^{1}$ Barry G. Grubbs, ${ }^{1}$ \\ Rotraud Wieser, ${ }^{2}$ Joan Massagué, ${ }^{2}$ Gregory R. Mundy, ${ }^{1}$ and Theresa A. Guise ${ }^{1}$ \\ ${ }^{1}$ Department of Medicine, University of Texas Health Science Center at San Antonio, San Antonio, Texas 78284-7877, USA \\ ${ }^{2}$ Howard Hughes Medical Institute, Memorial Sloan-Kettering Cancer Center, New York, New York, 10021 USA \\ Address correspondence to: T.A. Guise, Division of Endocrinology, Department of Medicine, University of Texas Health Science Center \\ at San Antonio, 7703 Floyd Curl Drive, San Antonio, Texas 78284-7877, USA. Phone: (210) 567-4900; Fax: (210) 567-6693; \\ E-mail: guise@uthscsa.edu \\ Juan Juan Yin and Katri Selander contributed equally to this work. \\ Received for publication March 25, 1998, and accepted in revised form December 1, 1998.
}

\begin{abstract}
Breast cancer frequently metastasizes to the skeleton, and the associated bone destruction is mediated by the osteoclast. Growth factors, including transforming growth factor- $\beta$ (TGF- $\beta$ ), released from bone matrix by the action of osteoclasts, may foster metastatic growth. Because TGF- $\beta$ inhibits growth of epithelial cells, and carcinoma cells are often defective in TGF- $\beta$ responses, any role of TGF- $\beta$ in metastasis is likely to be mediated by effects on the surrounding normal tissue. However, we present evidence that TGF- $\beta$ promotes breast cancer metastasis by acting directly on the tumor cells. Expression of a dominant-negative mutant (T $\beta \mathrm{RII} \Delta \mathrm{cyt}$ ) of the TGF- $\beta$ type II receptor rendered the human breast cancer cell line MDA-MB-231 unresponsive to TGF- $\beta$. In a murine model of bone metastases, expression of T $\beta$ RI$\mathrm{I} \Delta$ cyt by MDA-MB-231 resulted in less bone destruction, less tumor with fewer associated osteoclasts, and prolonged survival compared with controls. Reversal of the dominant-negative signaling blockade by expression of a constitutively active TGF- $\beta$ type I receptor in the breast cancer cells increased tumor production of parathyroid hormone-related protein (PTHrP), enhanced osteolytic bone metastasis, and decreased survival. Transfection of MDA-MB-231 cells that expressed the dominant-negative T $\beta$ RII $\Delta-$ cyt with the cDNA for PTHrP resulted in constitutive tumor PTHrP production and accelerated bone metastases. These data demonstrate an important role for TGF- $\beta$ in the development of breast cancer metastasis to bone, via the TGF- $\beta$ receptor-mediated signaling pathway in tumor cells, and suggest that the bone destruction is mediated by PTHrP.
\end{abstract}

J. Clin. Invest. 103:197-206 (1999).

\section{Introduction}

In 1889, Paget (1) proposed the "seed and soil" hypothesis to explain the predilection with which breast cancer grows in bone. Despite these observations, the mechanisms underlying the affinity with which breast cancer grows in bone are not completely understood. Breast cancer metastasizes to bone in greater than $80 \%$ of patients with advanced disease and causes local osteolysis (2). The associated pain, pathological fracture, hypercalcemia, and nerve compression syndromes are consequences of the bone destruction. These morbid complications can be devastating, because patients with breast cancer and bone metastases may survive for many years.

A unique characteristic of the skeleton is the storage within bone matrix of immobilized growth factors such as transforming growth factor (TGF)- $\beta$, insulin-like growth factor (IGF)-1 and -2, fibroblast growth factor (FGF)-1 and -2, and platelet-derived growth factors (3). The most abundant repository for TGF- $\beta$ is the bone matrix, and it is released locally in the microenvironment as a consequence of osteoclastic bone resorption (4). Thus, tumor cells with the capacity to stimulate osteoclastic bone resorption may enrich the bone microenvironment with growth factors that may alter behavior of tumor cells. Data in support of this include histological examination of breast cancer metastatic to bone, which reveals tumor cells adjacent to bone-resorbing osteoclasts (5). Bisphosphonates, potent inhibitors of osteoclastic bone resorption, decrease the morbidity associated with breast cancer bone metastases $(6,7)$. These findings indicate that the bone destruction by breast cancer is mediated by tumor stimulation of osteoclastic bone resorption.

Parathyroid hormone-related protein (PTHrP) is a tumor product (8-10) that stimulates osteoclastic bone resorption and renal tubular reabsorption of calcium by binding to a common $\mathrm{PTH} / \mathrm{PTHrP}$ receptor $(11,12)$. The majority of patients with solid tumors and hypercalcemia have increased plasma PTHrP concentrations (13). PTHrP may have a more common role in malignancy as a mediator of osteolytic bone metastasis in breast cancer, even in the absence of hypercalcemia. Women with PTHrP-positive primary breast tumors are more likely to develop bone metastases (14). Human breast cancer cells express PTHrP more often in bone (15) than in the primary (16) or soft tissue sites, and neutralizing antibodies to PTHrP inhibit the development of osteolytic metastases by human breast cancer cells in vivo (17). The reasons for increased expression of PTHrP in bone are unknown, but bone-derived growth factors may be responsible.

Because TGF- $\beta$ is one of the most abundant growth 
factors in bone matrix (3), is released in active form during osteoclastic bone resorption (4), and increases $\mathrm{PTHrP}$ expression by cancer cells in vitro (18-21), we postulated that TGF- $\beta$ was responsible for enhancing PTHrP production in the bone microenvironment and the subsequent bone destruction. To test this hypothesis, the human breast cancer cell line MDA-MB-231 (22) was transfected with a cDNA encoding a TGF- $\beta$ type II receptor lacking most of the cytoplasmic domain (T $\beta$ RII $\Delta$ cyt), which acts as a dominant-negative to block the biologic effects of TGF- $\beta$ (23). Expression of this mutant receptor in human breast cancer cells inhibited TGF- $\beta$-stimulated PTHrP production and blocked the growth inhibitory effects of TGF- $\beta$ in vitro. Blockade of TGF- $\beta$ responsiveness in breast cancer cells resulted in decreased osteolysis, less tumor burden in bone, and enhanced survival in mice bearing tumors that expressed the dominant-negative receptor. When TGF- $\beta$ responsiveness of the breast cancer cells expressing the dominant-negative type II receptor was restored by expression of a constitutively active TGF- $\beta$ type I receptor subunit, growth of tumor in bone and osteolysis were markedly enhanced, and survival was decreased. Because PTHrP production was increased fivefold in this tumor line, the data suggested that the effects of TGF- $\beta$ to enhance bone destruction were mediated by PTHrP. To confirm this notion, a cDNA-encoding human PTHrP was transfected into the breast cancer cells expressing the dominant-negative type II receptor. The resulting increase in constitutive PTHrP production in vitro was associated with accelerated bone metastases in vivo. $a$ $b$
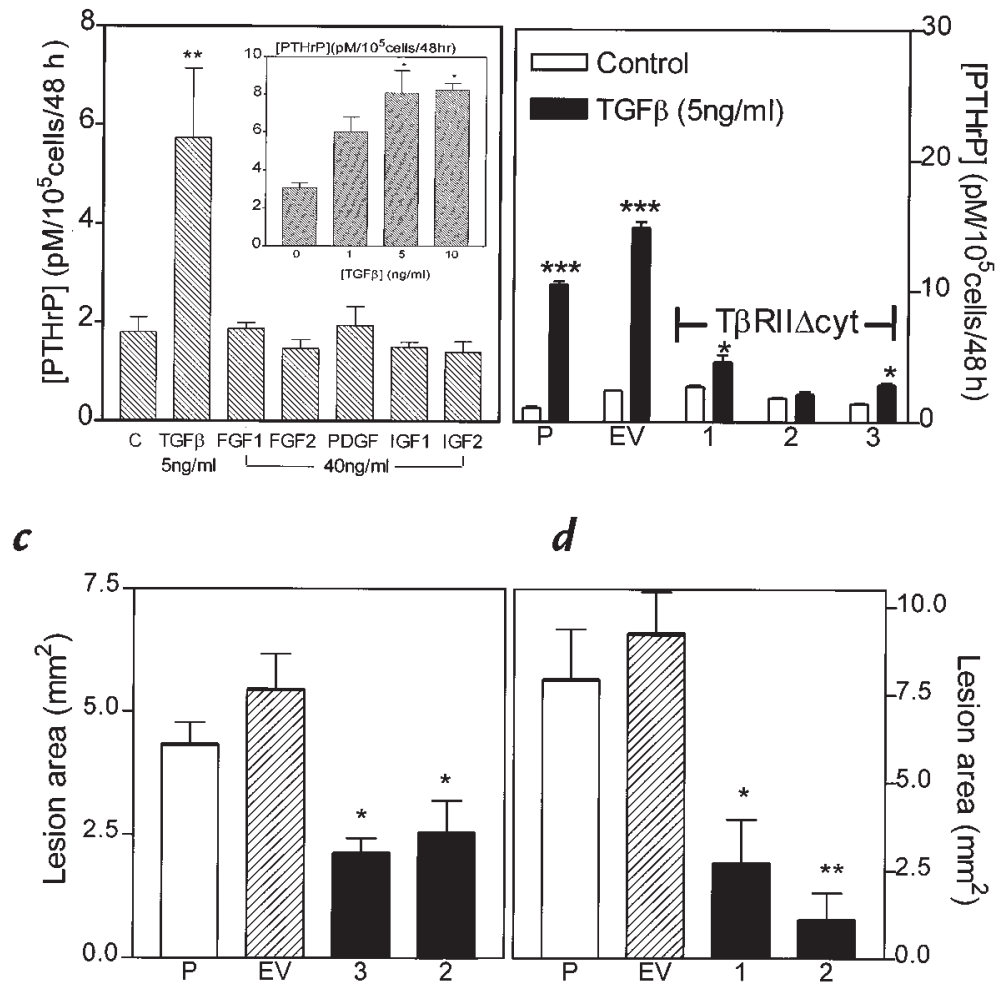

Figure 1

(a) Effects of bone growth factors on PTHrP secretion from MDA-MB-231 cells in vitro. MDA-MB-231 cells were plated onto 48-well plates and grown to near confluence. Cells were washed and treated with serum-free media containing the respective growth factors for $48 \mathrm{~h}$. PTHrP concentrations in conditioned media were corrected for cell number. Only the results for the highest concentration of each growth factor are shown. Inset: Dose response for PTHrP secretion by MDA-MB-231 cells treated with TGF- $\beta$. Values represent the mean $\pm \operatorname{SEM}(n=3$ per group).(b) Effect of TGF- $\beta$ on PTHrP secretion by MDA-MB$231, \mathrm{MDA} / \mathrm{pcDNA3}$, and MDA/T $\beta \mathrm{RII} \Delta$ cyt clones. Respective cells were plated onto 48well plates and treated as described in $a$. Values represent the mean $\pm \operatorname{SEM}(n=3$ per group). $P=$ parental MDA-MB-231; $E V=$ empty vector $\mathrm{pcDNA3}$ clone; 1,2 , and 3 are respective MDA/T $\beta R \| \Delta$ cyt clones. ( $\boldsymbol{c}$ and $\boldsymbol{d}$ ) Osteolytic lesion area from radiographs of two separate experiments comparing clones 3 and $2(c)$ or clones 1 and $2(d)$ with controls of MDA-MB-231 $(P)$ or pcDNA3 vector $(E V)$. Values represent mean \pm SEM $(n=4$ per group). ${ }^{*} P<0.05,{ }^{*} P<0.01,{ }^{*}{ }^{*} P<0.001$ vs. controls. $P T H r P$, parathyroid hormone-related protein; TGF- $\beta$, transforming growth factor- $\beta$.

\section{Methods}

Cells. MDA-MB-231 cells were cultured in DMEM (Life Technologies Inc., Rockville, Maryland, USA) containing 10\% FCS (HyClone Laboratories, Logan, Utah, USA), 1\% penicillin/streptomycin, and nonessential amino acids (GIBCO BRL, Gaithersburg, Maryland, USA). To test the effect of bone-derived growth factors on PTHrP secretion by MDA-MB-231 cells, $10^{4}$ cells $/ \mathrm{ml}$ were plated onto 48 -well plates. When near confluence, cells were washed with PBS, and $250 \mu \mathrm{l}$ of serum-free DMEM containing the following growth factors was added to each well: TGF- $\beta 1(0$, $1,5$, or $10 \mathrm{ng} / \mathrm{ml})$, FGF-1 $(0,4,20$, or $40 \mathrm{ng} / \mathrm{ml})$, FGF-2 $(0,4,20$, or $40 \mathrm{ng} / \mathrm{ml})$, PDGF $(0,1,5,10$, or $40 \mathrm{ng} / \mathrm{ml})$, IGF-1 $(0,1,5,10$, or $40 \mathrm{ng} / \mathrm{ml})$, and IGF- $2(0,1,5,10$, or $40 \mathrm{ng} / \mathrm{ml})$. TGF- $\beta 1$, FGF1, FGF-2, PDGF, IGF-1, and IGF-2 were purchased from R\&D Systems Inc. (Minneapolis, Minnesota, USA). Conditioned media were collected after $48 \mathrm{~h}$, stored at $-70^{\circ} \mathrm{C}$ for PTHrP measurement, and cell number was counted for each well to correct the PTHrP concentration of the conditioned media. Triplicate measurements were performed for each treatment.

To measure the effects of TGF- $\beta$ on the growth rate of MDA-
MB-231 cells and respective clones, $10^{4}$ cells $/ \mathrm{ml}$ were plated onto each of two 24 -well plates. One plate was treated with TGF- $\beta 1$ $(20 \mathrm{ng} / \mathrm{ml})$ and the other with vehicle. Cell number was counted daily for 8 days; each measurement was performed in triplicate.

Stable transfection of MDA-MB-231 cells with cDNA for the truncated type II TGF- $\beta$ receptor (T $\beta$ RII $\Delta$ cyt). T $\beta$ RII $\Delta$ cyt cDNA (23) was subcloned from pMEP4 into the pcDNA3 expression vector (Invitrogen Corp., Carlsbad, California, USA) as a HindIII-BamHI fragment. The pcDNA3/T $\beta$ RIIcyt DNA or the empty vector, pcDNA3, was transfected into MDA-MB-231 cells by calcium phosphate precipitation. Single clones were isolated by limiting dilution in the presence of the selective marker, G418 (Sigma Chemical Co., St. Louis, Missouri, USA). Clones were screened by measuring the amount of secreted PTHrP in serumfree 48 -h conditioned media in the presence or absence of TGF$\beta(5 \mathrm{ng} / \mathrm{ml})$. Clones in which PTHrP secretion did not increase in response to TGF- $\beta$ were selected for further study.

Stable transfection of MDA/T $\beta R I I \Delta c y t$ with cDNA for the constitutively active type I TGF- $\beta$ receptor T $\beta R I(T 204 D)$ ). The 

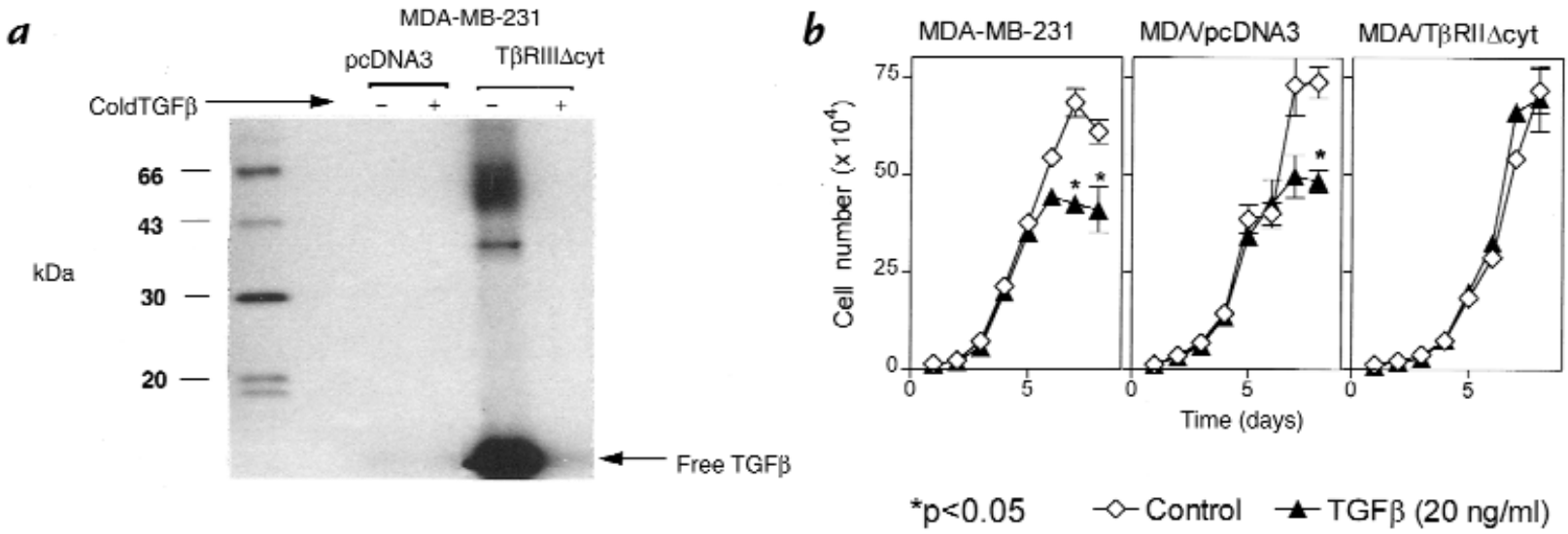

Figure 2

(a) ${ }^{125}$-labeled TGF- $\beta 1$ cross-linking followed by immunoprecipitation with anti-HA antibody in clonal MDA-MB-231 cells expressing the T $\beta$ RII $\Delta$ cyt (MDA/T $\beta R / I \Delta c y t)$ or the empty vector (MDA/pcDNA3). Clonal lines were cross-linked with 160 pM ${ }^{125}$-labeled TGF- $\beta 1$ alone (-) or in the presence of excess unlabeled TGF- $\beta 1(5 \mathrm{nM})(+)$. Cell extracts were subjected to SDS-PAGE and autoradiography to visualize the truncated receptor. (b) Effect of TGF- $\beta$ on growth rate of MDA-MB-231, MDA/pcDNA3, and MDA/T $\beta R$ III $\Delta$ cyt cells. Respective cells were plated at a density of $10^{4}$ cells per well with or without TGF- $\beta(20 \mathrm{ng} / \mathrm{ml})$ in $10 \%$ FCS and counted daily. Values represent the mean \pm SEM ( $n=3$ per group). In the absence of TGF- $\beta$, growth rates of each cell line did not significantly differ.

T $\beta R I(T 204 D)$ cDNA insert $(24,25)$ was subcloned into pcDNA3.1zeo (Invitrogen Corp.) as a HindIII-BamHI fragment. The pcDNA3.1zeo/T $\beta$ RI(T204D) DNA or the empty vector, pcDNA3.1zeo, was transfected into the MDA-MB231 clonal line expressing the truncated type II TGF- $\beta$ receptor, MDA/T $\beta$ RII $\Delta$ cyt, by calcium phosphate precipitation. Single clones were isolated by limiting dilution in the presence of the selective markers, G418 and zeocin (Invitrogen Corp.), and screened as described. Clones with increased PTHrP production, basally and in response to TGF- $\beta 1$, were selected for further study.

Stable transfection of MDA/TARIIAcyt with cDNA for PTHrP. Human preproPTHrP cDNA encoding the 1-141 isoform was subcloned from pCMVIE-AK1-DHFR (26) into pcDNA3.1zeo (Invitrogen Corp.) as a HindIII-BamHI fragment. The pcDNA3.1zeo/PTHrP DNA or the empty vector, pcDNA3.1zeo, was transfected into the MDA-MB-231 clonal line expressing the truncated type II TGF- $\beta$ receptor, MDA/T $\beta$ RII $\Delta$ cyt, by calcium phosphate precipitation. Single clones were isolated by limiting dilution in the presence of both selective markers, G418 and zeocin (Invitrogen Corp.), and screened as described. Clones with increased PTHrP production, in the basal state, and which did not respond to TGF- $\beta 1$, were selected for further study.

Cross-linking and immunoprecipitation. MDA-MB-231 clones expressing either T $\beta$ RII $\Delta$ cyt (MDA/T $\beta R I I \Delta c y t$ ) or the empty vector (MDA/pcDNA3) were plated onto two $10-\mathrm{cm}$ petri dishes $\left(10^{6}\right.$ cells per dish). Cells were grown to confluence and incubated for $3 \mathrm{~h}$ at $4^{\circ} \mathrm{C}$ with ${ }^{125}$ I-labeled TGF- $\beta 1$ (160 pM) (Du Pont Nen Research Products, Boston, Massachusetts, USA) alone or with cold TGF- $\beta 1$ ( $5 \mathrm{nM})$ as a competitor (23). After washing away the unbound TGF- $\beta 1$, ligand-receptor was cross-linked with disuccinimidyl suberate and solubilized with $10 \mathrm{mM}$ Tris buffer ( $\mathrm{pH}$ 7.4) containing 1\% Triton X-100, 1 mM EDTA, and protease inhibitors. The receptor complexes were immunoprecipitated with $2.5 \mu \mathrm{g} / \mathrm{ml}$ mouse anti-HA monoclonal antibody, 12CA5 (Boehringer Mannheim Biochemicals, Indianapolis, Indiana, USA), followed by adsorption to protein G-Sepharose (Pharmacia Biotech Inc., Piscataway, New Jersey, USA). This mixture was washed, and bound protein was eluted by heating samples in SDS-PAGE sample buffer containing $100 \mathrm{mM}$ dithiothreitol. Samples were run on $12.5 \%$ SDS-PAGE gels under reducing conditions, and gels were fixed, dried, and exposed to film at $-70^{\circ} \mathrm{C}$.

\section{Animals}

Animal protocols were approved by the Institutional Animal Care and Use Committee at the University of Texas Health Science Center at San Antonio and were in accordance with the National Institutes of Health Guide for the Care and Use of Laboratory Animals. Female nude mice 4 weeks of age were housed in laminar flow isolated hoods. Water supplemented with vitamin $\mathrm{K}$ and autoclaved mouse chow were provided ad libitum. Whole blood samples for ionized calcium concentration were obtained by retro-orbital puncture under metofane anesthesia. Blood for PTHrP measurement was similarly obtained and collected on ice in Vacutainer tubes containing EDTA and $400 \mathrm{IU} / \mathrm{ml}$ aprotinin (Sigma Chemical Co.). Tumor inoculation into the left cardiac ventricle was performed as described previously (17).

\section{Experimental protocols}

Bone metastasis. In the pilot experiments (Fig. 1, $c$ and $d$ ), mice were inoculated with tumor-cell suspensions of MDA/T $\beta R I-$ I $\Delta$-cyt (independent clones: 1,2 , and 3), MDA/pcDNA3, or parental MDA-MB-231 cells into the left cardiac ventricle ( $n$ $=4$ per group) on day 0 . At sacrifice, on day 28 , radiographs were obtained and analyzed as described later in this paper. Because MDA/T $\beta$ RII $\Delta$ cyt, clone 2, was the least responsive to TGF- $\beta$ in vitro (Fig. $1 b$ ), more detailed experiments were performed comparing this clone with the controls. In the first set of experiments, mice were inoculated with tumor-cell suspensions of MDA/T $\beta$ RII $\Delta$ cyt (clone 2), MDA/pcDNA3, or parental MDA-MB-231 cells into the left cardiac ventricle ( $n$ = 13 per group) on day 0 after baseline radiographs, body weights, and blood for $\mathrm{Ca}^{2+}$ and plasma PTHrP concentrations were obtained. Radiographs were taken on day 21 and at sacrifice on day 24 to monitor progression of osteolytic metastases. $\mathrm{Ca}^{2+}$ and body weight were measured weekly after tumor inoculation until sacrifice, at which time most control mice were cachectic and paraplegic. Blood was collected for $\mathrm{Ca}^{2+}$ and PTHrP measurement, and all bones and soft tissues were fixed in formalin for histologic analysis. Autopsy was performed on all mice, and those with tumor in the chest were excluded from analysis, because this indicated that the tumor inoculum did not properly enter the left cardiac ventricle. A separate experiment was similarly performed to assess sur- 


\section{Figure 3}

(a) Representative radiographs of hindlimbs from mice bearing MDA-MB-231, MDA/pcDNA3, or MDA/T $\beta R I I \Delta$ cyt tumors 24 days after tumor inoculation. Osteolytic lesions are indicated by the arrows. (b) Osteolytic lesion number and area on radiographs as measured by computerized image analysis of forelimbs and hindlimbs. Respective tumor cells were inoculated on day 0 . Values represent the mean $\pm \operatorname{SEM}(n=13$ per group). (c) Histomorphometric analysis of forelimbs and hindlimbs from mice with osteolytic lesions. Data represent measurements from midsections of tibiae, femora, and humeri of mice from $b$, inoculated with either MDA-MB-231, MDA/pcDNA3, or MDA/T $\beta R I I \Delta$ cyt clone 2. Tumor area $\left(\mathrm{mm}^{2}\right)$ from metastatic bone lesions is illustrated on the right and osteoclast number per millimeter of tumor adjacent to bone (tumor/bone interface) on the left. Values represent the mean \pm SEM.

vival. In this experiment, mice were sacrificed when they became moribund.

In the second set of experiments, female mice were inoculated with tumor-cell suspensions of clonal MDA-MB231 lines T $\beta$ RII $\Delta$ cyt $+\mathrm{T} \beta \mathrm{RI}(\mathrm{T} 204 \mathrm{D})$ or $\mathrm{T} \beta \mathrm{RII} \Delta$ cyt + pcDNA3.1zeo into the left cardiac ventricle on day 0. Radiographs, body weight, and blood for $\mathrm{Ca}^{2+}$ and PTHrP were obtained at baseline and sacrifice as in the first set of experiments. $\mathrm{Ca}^{2+}$, body weight, and radiographs were monitored weekly for 4 weeks, at which time the mice were sacrificed. Tissue processing, autopsy, data analysis, and a separate survival experiment were performed as in the first experiment.

In the third set of experiments, female mice were inoculated with tumor-cell suspensions of clonal MDA-MB-231 lines T $\beta$ RII $\Delta$ cyt + PTHrP (two different clones) or T $\beta$ RI$\mathrm{I} \Delta \mathrm{cyt}+\mathrm{pcDNA3}$.1zeo into the left cardiac ventricle on day 0 . The same parameters were measured as in the previous experiments. Two separate experiments were performed using two different T $\beta R I I \Delta c y t+P T H r P$ clones. Four T $\beta R I-$ $\mathrm{I} \Delta \mathrm{cyt}+\mathrm{PTHrP}$ clones were studied in total.

Local tumor growth. To investigate whether expression of the dominant-negative type II TGF- $\beta$ receptor subunit in breast cancer cells altered tumor growth in sites other than bone, tumor-cell suspensions $\left(10^{7} / 100 \mu \mathrm{l} \quad \mathrm{PBS}\right)$ of either MDA/T $\beta$ RII $\Delta$ cyt, MDA/pcDNA3, or parental MDA-MB-231 cells were inoculated into the right thigh of female nude mice. Tumor volume was measured with calipers and calculated by the formula of an ovoid where $L$ equals midaxis length and $W$ equals midaxis width: tumor volume $=4 / 3 \pi \times L / 2(\mathrm{~W} / 2)^{2}$.

\section{Analytical methods}

$\mathrm{Ca}^{2+}$ measurement. $\mathrm{Ca}^{2+}$ concentrations were measured in whole blood using a Ciba Corning 634 ISE $\mathrm{Ca}^{2+} / \mathrm{pH}$ analyzer (Corning Medical and Scientific Medfield, Massachusetts, USA) as described previously (17).

PTHrP assay. PTHrP concentrations were measured in conditioned media and plasma using a two-site immunoradiometric assay (Nichols Institute, San Juan Capistrano, California, USA) that detects PTHrP-(1-72) and has a calculated sensitivity of 0.3 $\mathrm{pmol} / \mathrm{l}$ (27). PTHrP concentrations in conditioned media samples were calculated from a standard curve generated by adding recombinant PTHrP-(1-86) to the specific type of medium (unconditioned) used and were considered undetectable if media concentrations were $<0.3 \mathrm{pmol} / 1$ before correction for cell number.

Radiographs and measurement of osteolytic lesion area. Animals were $\mathrm{x}$-rayed in a prone position against the film as described previously (17). All radiographs were evaluated without knowledge of treatment groups. The area of osteolytic bone metastases was cal-

$\boldsymbol{b}$

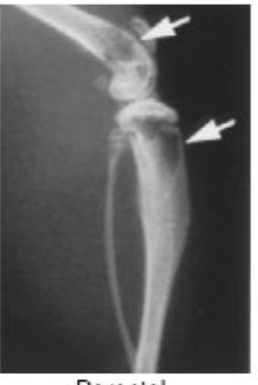

Parental

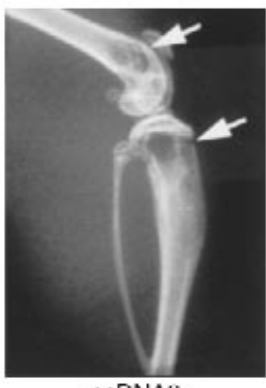

pcDNA3

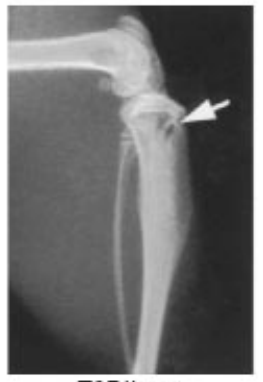

$T \beta R \| \Delta c y l$
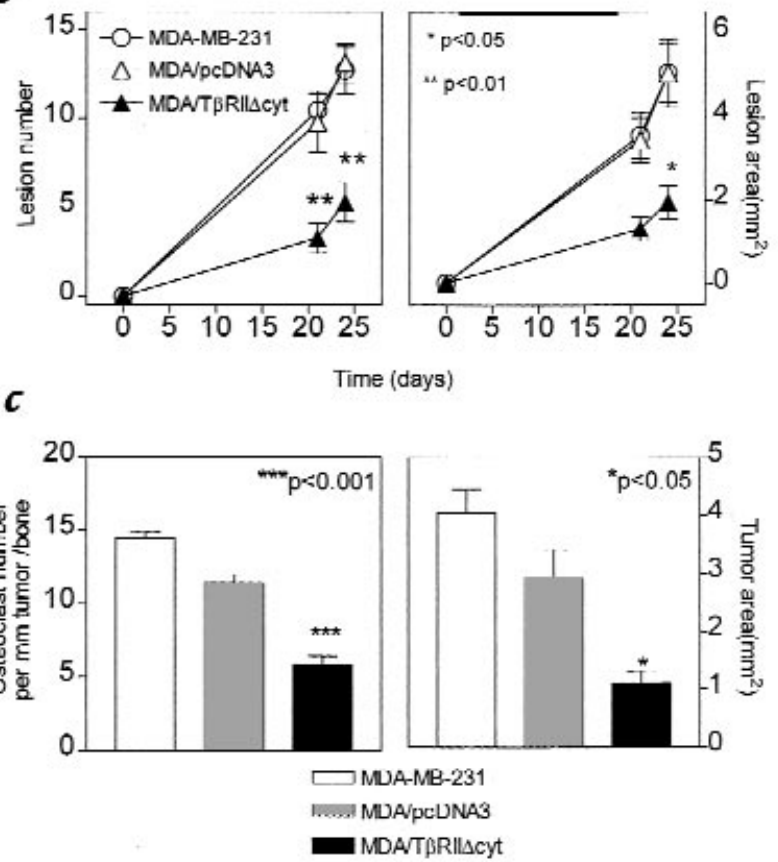

culated using a computerized image analysis system. Video images of radiographs were captured using a frame grabber board on a PC system. Quantitation of lesion area was performed using image analysis software (Java, Jandal Video analysis; Jandel Scientific, Corte Madera, California, USA).

Bone histology and histomorphometry. Forelimb and hindlimb bones were removed from mice at time of killing, fixed in $10 \%$ buffered formalin, decalcified in 14\% EDTA, and embedded in paraffin wax. Sections were stained with hematoxylin, eosin, orange G, and phloxine. The following variables were measured in midsections of tibiae and femora, without knowledge of experimental groups, to assess tumor involvement: total tumor area and osteoclast number per millimeter of tumor/bone interface. Histomorphometric analysis was performed on an OsteoMeasure System (Osteometrics Inc., Atlanta, Georgia, USA).

\section{Statistical analysis}

Results are expressed as the mean \pm SEM. Data were analyzed by analysis of variance followed by Tukey-Kramer post test. Log-rank test (Wilcox survival) was used to analyze survival data. $P<0.05$ was considered significant.

\section{Results}

Effects of bone growth factors on PTHrP production in vitro by $M D A-M B-231$ cells. Because previous clinical and experimental studies demonstrated increased PTHrP expression by breast cancer cells in the bone microenviron- 


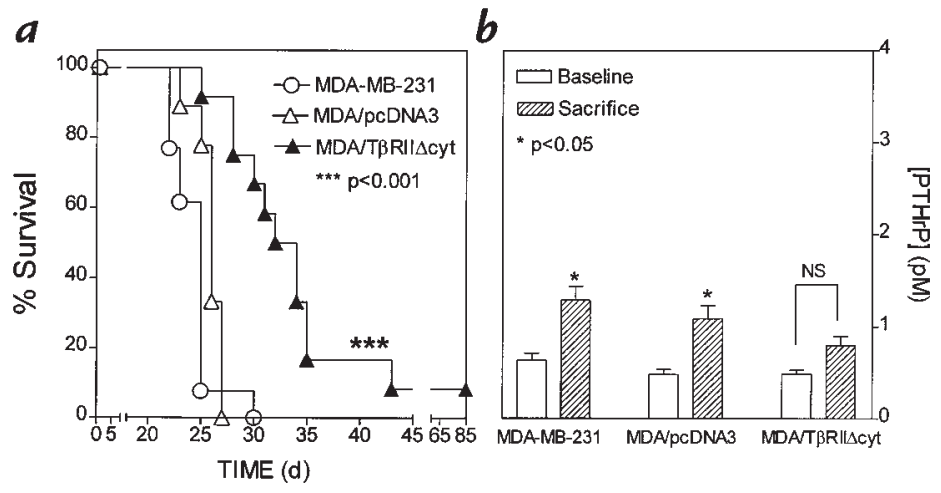

\begin{abstract}
Figure 4
Survival $(\boldsymbol{a})$ and plasma PTHrP concentrations $(\boldsymbol{b})$ in mice bearing MDA-MB-231, MDA/pcDNA3, or MDA/T $\beta R I I \Delta-$ cyt tumors. (a) Survival of mice bearing MDA/T $\Delta R \| \Delta$ cyt tumors was significantly longer than that of the controls. (b) Plasma PTHrP concentrations at sacrifice were significantly higher than respective concentrations before tumor inoculation (baseline) in mice bearing control tumors of MDA-MB-231 or MDA/pcDNA3. There was no significant difference between baseline and sacrifice values in mice bearing the MDA/T $\beta R I I \Delta$ cyt tumors.
\end{abstract}

ment, the effect of factors known to be present in bone matrix were tested on PTHrP production by human MDA-MB-231 breast cancer cells in vitro. Only TGF- $\beta$ significantly increased PTHrP production by these cells in a dose-dependent manner (Fig. 1a). Other growth factors abundant in bone, such as FGF-1 and -2, IGF-1 and -2 , and PDGF, had no effect on PTHrP secretion over a wide range of concentrations.

Expression of a truncated type II TGF- $\beta$ receptor (T $\beta$ RIIAcyt) in MDA-MB-231 cells. TGF- $\beta$ was the only factor tested that affected PTHrP secretion, so its role in breast cancer metastasis to bone was investigated by transfecting MDA-MB-231 cells with the cDNA for a truncated type II TGF- $\beta$ receptor (MDA/T $\beta$ RII $\Delta$ cyt) and generating clonal lines. This receptor is truncated at the intracytoplasmic domain and has 199 amino acids and a predicted protein size of $22 \mathrm{kDa}$. A hemagglutinin (HA) epitope is present in the extracellular domain. The mutant receptor binds TGF- $\beta$, but because it cannot phosphorylate the type I receptor, signal propagation does not occur (23). Thus, it acts in a dominant-negative fashion to block the biologic effects of TGF- $\beta$.

As shown in Fig. 1b, treatment of parental MDA-MB231 cells and the MDA/pcDNA3 clone with TGF- $\beta 1$ (5 $\mathrm{ng} / \mathrm{ml}$ ) significantly stimulated PTHrP secretion, while the same treatment of three different MDA/T $\beta$ RII $\Delta$ cyt resulted in minimal or no increase. Similar results were observed when the clones MDA/T $\beta$ RII $\Delta$ cyt and $\mathrm{MDA} / \mathrm{pcDNA} 3$ were grown in the absence of the selective marker, G418, for four weeks and indicate that $\mathrm{T} \beta \mathrm{RII} \Delta \mathrm{cyt}$ was stably expressed. These data demonstrate that T $\beta$ RII $\Delta$ cyt acts as a dominant-negative to block the biologic effects of TGF- $\beta$ to stimulate PTHrP production by MDA-MB-231 breast cancer cells. In two separate pilot experiments using a mouse model of bone metastases, all three MDA/T $\beta$ RII $\Delta$ cyt clones had smaller total osteolytic lesion area on radiographs compared with parental or empty vector controls (Fig. 1, $c$ and $d$ ). Because MDA/T $\beta$ RII $\Delta$ cyt clone 2 was the least responsive to TGF- $\beta$, it was studied in further detail.

Receptor expression in stable clones was demonstrated by cross-linking to ${ }^{125}$ I-labeled TGF- $\beta 1$. Figure $2 a$ demonstrates the autoradiograph of ${ }^{125}$ I-labeled TGF- $\beta 1$ crosslinking followed by immunoprecipitation with anti-HA antibody in clonal MDA-MB-231 cells expressing the T $\beta$ RII $\Delta$ cyt (MDA/T $\beta$ RII $\Delta$ cyt, clone 2 ) or the empty vector (MDA/pcDNA3). Two distinct bands, which were completely competed by cold TGF- $\beta$, were present in
MDA/T $\beta$ RII $\Delta$ cyt. One band had a molecular weight corresponding to the predicted size of the truncated TGF- $\beta$ type II receptor plus TGF- $\beta$ dimer $(47 \mathrm{kDa})$. The other band corresponded to the truncated type II TGF- $\beta$ receptor plus TGF- $\beta$ monomer, which has a predicted size of $34 \mathrm{kDa}$. No bands were evident by immunoprecipitation with the anti-HA antibody in the MDA/pcDNA3 clonal cells, which indicates that only MDA/T $\beta$ RII $\Delta$ cyt expressed the truncated type II TGF- $\beta$ receptor. These results also indicate that in the MDA/T $\beta$ RII $\Delta$ cyt, this mutant TGF- $\beta$ type II receptor was expressed at the cell surface and bound TGF- $\beta$. Endogenous type II TGF- $\beta$ receptor was expressed by both cell lines, as demonstrated by ${ }^{125}$ I-labeled TGF- $\beta 1$ cross-linking followed by immunoprecipitation with a polyclonal type II TGF- $\beta$ receptor antibody (data not shown).

Effect of TGF- $\beta$ on growth of $M D A-M B-231, M D A / p c D N A 3$, and MDA/T $\beta R I I \Delta$ cyt clonal cells. Because TGF- $\beta$ also regulates cellular functions of proliferation and differentiation, the effects of TGF- $\beta$ on growth of parental MDAMB-231, MDA/T $\beta$ RII $\Delta$ cyt (clone 2) and MDA/pcDNA3 clonal cells were studied. As illustrated in Fig. $2 b$, growth rates were similar for all three cell lines in the absence of TGF- $\beta$. TGF- $\beta 1(20 \mathrm{ng} / \mathrm{ml})$ inhibited the growth of parental MDA-MB-231 and MDA/pcDNA3 cells but had

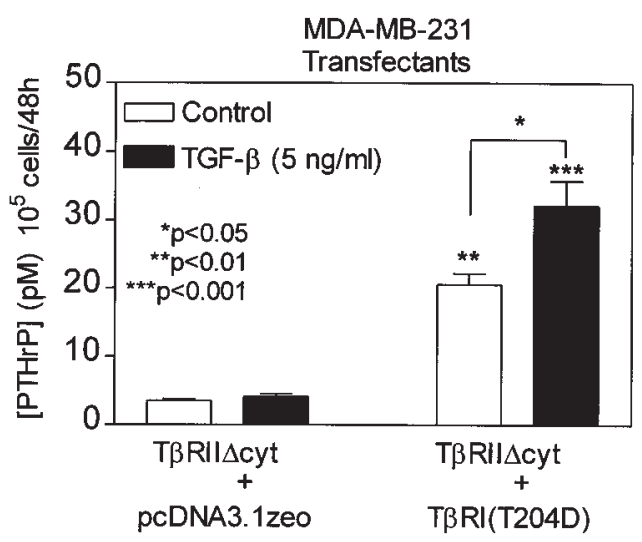

\section{Figure 5}

Effect of TGF- $\beta$ on PTHrP secretion by MDA-MB-231 clonal lines, T $\beta R I I \Delta-$ cyt + T $\beta R I(T 204 D)$, and T $\beta R I I \Delta c y t+p c D N A 3.1 z e o$. Respective cells were plated onto 48-well plates and treated as in Fig. 1a. Values represent the mean $\pm \operatorname{SEM}\left(n=3\right.$ per group). ${ }^{* *} P<0.01$ and ${ }^{* * *} P<0.001$ compared with T $\beta$ RII $\Delta$ cyt $+p c D N A 3.1 z e o$ (control or TGF- $\beta$-stimulated). 


\section{Figure 6}

(a) Representative radiographs of hindlimbs from mice bearing T $\beta R I I \Delta-$ $c y t+T \beta R I(T 204 D)$ or T $\beta R I I \Delta c y t+p c D N A 3.1 z e o 28$ days after tumor inoculation. Osteolytic lesions are indicated by the arrows. (b) Osteolytic lesion number and area on radiographs as measured by computerized image analysis of forelimbs and hindlimbs. Respective tumor cells were inoculated on day 0 . Values represent the mean $\pm \operatorname{SEM}(n=5$ per group). (c) Histomorphometric analysis of hindlimbs from mice with osteolytic lesions. Data represent measurements from midsections of tibiae and femora of mice (from $b$ ) inoculated with either T $\beta R I I \Delta c y t+T \beta R I(T 204 D)$ or T $\beta R I I \Delta c y t+p c D N A 3.1 z e o$ tumors. Tumor area $\left(\mathrm{mm}^{2}\right)$ from metastatic bone lesions is illustrated on the right and osteoclast number per millimeter of tumor adjacent to bone (tumor/bone interface) on the left. Values represent the mean \pm SEM. $(\boldsymbol{d})$ Bone histology from the midtibial metaphysis of representative mice bearing either T $\beta R I I \Delta$ cyt + T $\beta R I(T 204 D)$ or T $\beta R I I \Delta c y t+p c D N A 3.1 z e o$ tumors. Tumor (arrows) filled the marrow cavity and replaced normal cellular elements in mice bearing T $\beta$ RII $\Delta$ cyt $+\mathrm{T} \beta \mathrm{RI}(\mathrm{T} 204 \mathrm{D}$ ) tumors (right). There was significant loss of both cortical and trabecular bone in this group, and tumor has eroded through the growth plate. In contrast, sections from mice bearing control T $\beta R I I \Delta c y t+p c D N A 3.1 z e o$ tumors (left) had small foci of tumor in the marrow cavity (arrows) with little bone destruction, as evidenced by intact trabecular and cortical bone.

no effect on MDA/T $\beta$ RII $\Delta$ cyt. Thus, expression of the dominant-negative receptor blocked TGF- $\beta$-mediated growth inhibition of MDA-MB-231 cells.

Role of TGF- $\beta$ in breast cancer metastases to bone. To determine the effects of TGF- $\beta$ on breast cancer-mediated osteolysis, MDA/T $\beta$ RII $\Delta$ cyt (clone 2) or controls were studied in a mouse model of bone metastasis (17). Respective tumor cells were inoculated into the left cardiac ventricle of female nude mice, and serial radiographs were obtained. Representative radiographs from mice 24 days after tumor inoculation are illustrated in Fig. 3a. Osteolytic lesion number and area on radiographs were significantly less in MDA/T $\beta R I I \Delta$ cyt-bearing mice compared with that of MDA/pcDNA3 and MDA-MB-231 controls (Fig. 3b). These data were consistent with the pilot experiments in which two other MDA/T $\beta R I I \Delta$ cyt clones, in addition to clone 2, had significantly fewer and smaller bone metastases on radiographs compared with controls (Fig. 1, $c$ and $d$ ).

Because radiographic methods assess only bone destruction and are not a direct measurement of tumor area in bone, histomorphometric analysis of forelimb and hindlimb bones was performed. Osteoclast number per millimeter of tumor/bone interface and tumor area in bone was significantly less in MDA/T $\beta$ RII $\Delta$ cyt-bearing mice compared with $\mathrm{MDA} / \mathrm{pcDNA} 3$ and MDA-MB231 controls (Fig. 3c).

In a separate experiment, survival of mice bearing MDA/T $\beta$ RII $\Delta$ cyt was significantly longer than that of the controls (Fig. 4a). In all experiments, there were no differences between MDA/T $\beta \mathrm{RII} \Delta$ cyt and control groups with regard to metastasis to nonbone sites. Gross and histological assessment of soft tissues revealed little or no metastasis to adrenal glands, lungs, liver, spleen, ovaries, brain, or kidneys. In this survival experiment, plasma PTHrP concentrations were higher in the control groups, MDA/pcDNA3 and MDA-MB-231, at the time a

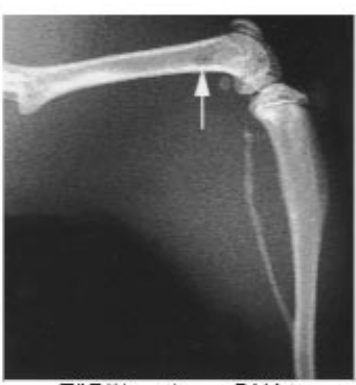

$T \beta R I I(\Delta c y t)+p c D N A 3$

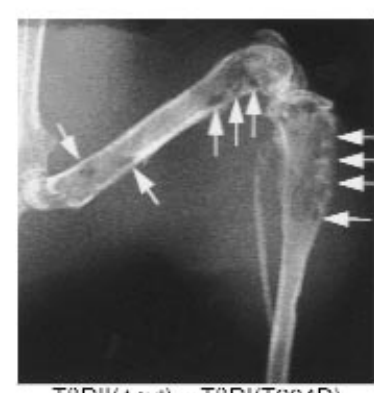

$T / \beta R I I(\Delta c y t)+T \beta R /(T 204 D)$ b

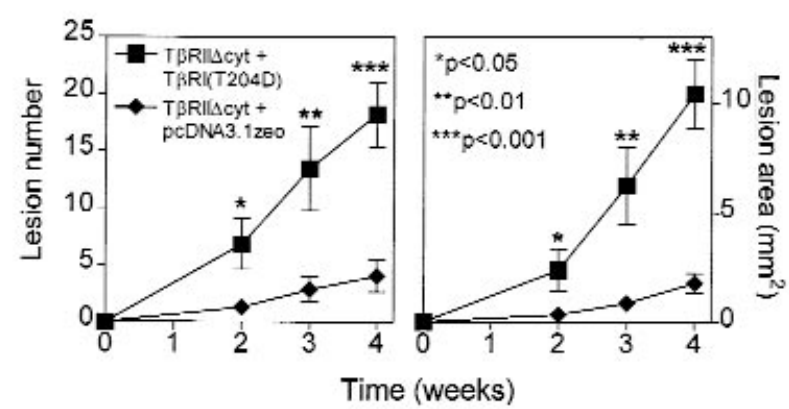

C
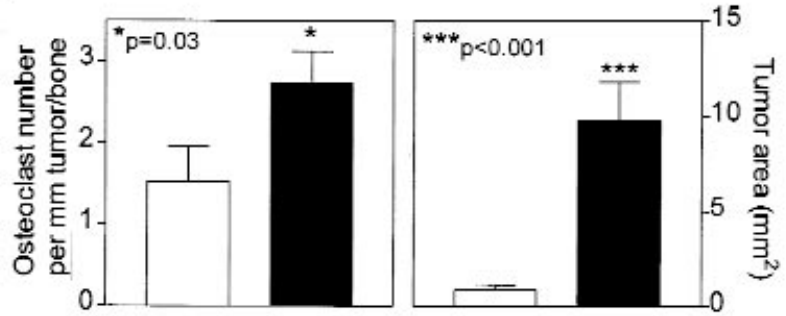

$\square T B R \| I C y t+p c D N A 3.1 z e o$

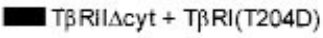

$d$
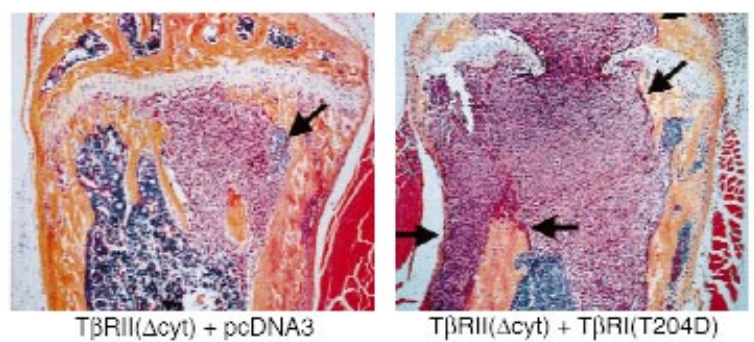

of death compared with baseline measurements. PTHrP concentrations did not differ from baseline to sacrifice in the MDA/T $\beta$ RII $\Delta$ cyt group (Fig. $4 b$ ).

Effect of T $\beta R I I \Delta$ cyt on local tumor growth. Although there were no differences in metastasis to nonbone sites between MDA/T $\beta R I I \Delta c y t$ and control groups, there were insufficient metastases to determine whether expression of the dominant-negative receptor significantly affected tumor growth at sites other than bone. Thus, tumor-cell suspensions ( $10^{7}$ cells $/ 100 \mu \mathrm{l} /$ mouse) of MDA/T $\beta R I I \Delta$ cyt, MDA/pcDNA3, or MDA-MB-231 cells were inoculated intramuscularly into the right thigh of female athymic nude mice. Tumors were excised, measured, and weighed at sacrifice, 21 days after tumor inoculation. 

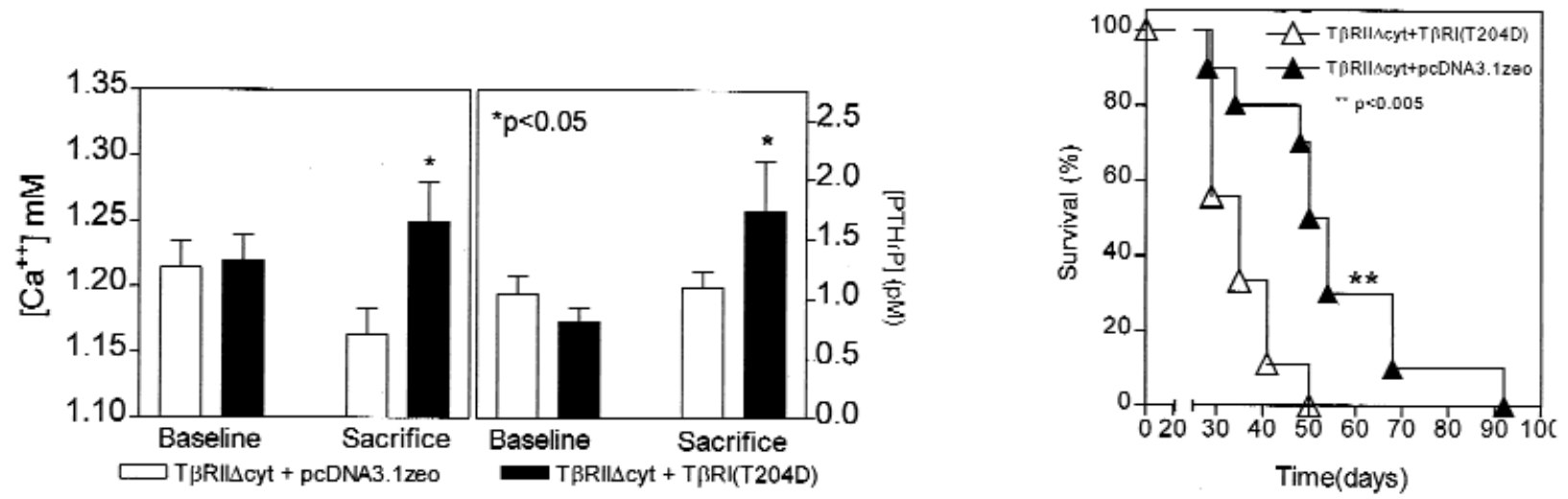

Figure 7

(a) Plasma PTHrP concentrations (right) and whole blood ionized calcium concentrations (left) at sacrifice were significantly higher than respective concentrations before tumor inoculation (baseline) in mice bearing tumors T $\beta R I I \Delta c y t+T \beta R I(T 204 D)$. There was no significant difference between

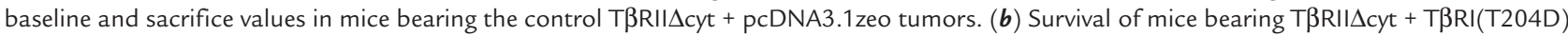
was significantly shorter than that of the controls, T $\beta$ RII $\Delta c y t+\operatorname{pcDNA3.1zeo~(~} n=10$ per group).

Tumor volume and tumor weight did not differ significantly between the groups (data not shown).

Restoration of TGF- $\beta$ responsiveness into MDA/T $\beta R I I \Delta c y t$ by expression of a constitutively active type I TGF- $\beta$ receptor. To confirm that the decrease in bone metastasis was due to blockade of TGF- $\beta$ signaling, the effects of the dominant-negative type II receptor mutation were reversed by the introduction of a constitutively active form of the type I receptor, T $\beta R$-I. This receptor has a point mutation at amino acid 204 of the GS domain in which aspartic acid replaces threonine (T204D). In TGF- $\beta$ signal transduction, T $\beta R$-II phosphorylates T $\beta R$-I, which then propagates the signal (28). TRRI(T204D) is constitutively phosphorylated and does not require ligand binding or interaction with the type II receptor to mediate TGF- $\beta$ signaling (24). TGF- $\beta$ did not stimulate PTHrP production in the T $\beta \mathrm{RI}$ $\mathrm{I} \Delta \mathrm{cyt}+\mathrm{pcDNA3}$.1zeo clone (empty vector control). However, there was a fivefold increase in the basal production of PTHrP by the T $\beta R I I \Delta c y t+T \beta R I(T 204 D)$ clone that was further enhanced by TGF- $\beta$ (Fig. 5). Thus, expression of the constitutively active TGF- $\beta$ type I receptor overcame the dominant-negative blockade and restored the TGF- $\beta$-stimulated PTHrP production.

Next, to study the effect of the restoration of TGF- $\beta$ responsiveness, MDA-MB-231 clonal lines of T $\beta$ RII $\Delta-$ $c y t+T \beta R I(T 204 D)$ or T $\beta$ RII $\Delta c y t+$ pcDNA3.1zeo control cells were inoculated into the left cardiac ventricle of female nude mice, and serial radiographs were obtained. Four weeks after tumor inoculation, mice bearing T $\beta$ RII $\Delta$ cyt + T $\beta$ RI(T204D) tumors had significantly more and larger osteolytic lesions on radiographs compared with those bearing T $\beta$ RII $\Delta$ cyt + pcDNA3.1zeo tumors (Fig. 6, $a$ and $b$ ). Histomorphometric analysis of hindlimbs supported the radiographic findings and revealed that the osteoclast number per millimeter of tumor/bone interface and tumor area in bone was significantly greater in the T $\beta R I I \Delta c y t$ $+\mathrm{T} \beta \mathrm{RI}(\mathrm{T} 204 \mathrm{D})$ group when compared with the control group, T $\beta$ RII $\Delta$ cyt + pcDNA3.1zeo (Fig. 6c). Histological sections of the midtibial metaphysis from mice bearing
T $\beta$ RII $\Delta$ cyt $+\mathrm{T} \beta \mathrm{RI}(\mathrm{T} 204 \mathrm{D})$ demonstrate tumor replacing the marrow cavity and destruction of both trabecular and cortical bone, whereas bones from mice bearing T $\beta$ RII $\Delta$ cyt + pcDNA3.1zeo had small foci of tumor in the bone marrow cavity with little bone destruction (Fig. 6d). Plasma PTHrP and blood ionized calcium concentrations were also significantly higher in mice bearing $\mathrm{T} \beta \mathrm{RII} \Delta$ cyt $+\mathrm{T} \beta \mathrm{RI}(\mathrm{T} 204 \mathrm{D})$ tumors compared with those bearing the control, T $\beta$ RII $\Delta$ cyt + pcDNA3.1zeo (Fig. 7a). In a separate experiment, mice bearing the TGF$\beta$-responsive tumor, T $\beta R I I \Delta c y t+T \beta R I(T 204 D)$, had a significantly shorter survival time than mice bearing the tumors that were unresponsive to TGF- $\beta$ (Fig. 7b).

Overexpression of PTHrP, under the control of a constitutive promoter, into $M D A / T \beta R I I \Delta c y t$. To determine whether the effects of TGF- $\beta$ to enhance bone metastases were mediated by PTHrP, the MDA/T $\beta$ RII $\Delta$ cyt clonal line was transfected with the cDNA encoding human preproPTHrP-(1-141) under the control of a constitutive CMV promoter. Figure $8 a$ demonstrates that basal PTHrP secretion in vitro was greater in two different $\mathrm{T} \beta \mathrm{RII} \Delta$ cyt + PTHrP clones compared with the T $\beta$ RII $\Delta$ cyt + pcDNA3.1zeo control. PTHrP secretion did not increase in response to TGF- $\beta$ in any clone expressing the dominant-negative type II receptor (Fig. 8a). Next, the effect of PTHrP overexpression by MDA/T $\beta$ RII $\Delta$ cyt was studied in vivo. Thirty-one days after tumor inoculation, mice bearing either T $\beta$ RII $\Delta c y t+P T H r P$ clone had significantly larger and more osteolytic lesions on radiographs compared with those bearing T $\beta$ RII $\Delta c y t+p c D N A 3$.1zeo tumors (Fig. 8, $b$ and $c$ ). At the time of sacrifice, plasma $\mathrm{PTHrP}$ concentrations (Fig. 8d) were significantly greater in both T $\beta R I I \Delta c y t+$ PTHrP groups compared with the TRRII-cyt + pcDNA3.1zeo control group, as were blood ionized calcium concentrations (data not shown).

\section{Discussion}

Breast cancer metastasizes to bone in greater than $80 \%$ of patients with advanced disease and causes local bone destruction (2) with subsequent pain, fracture, hyper- 


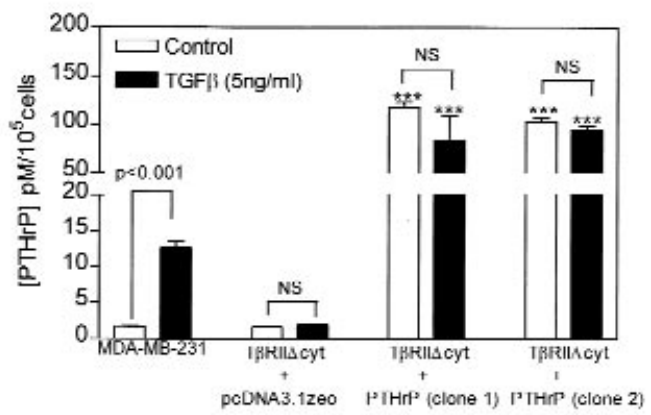

MDA-MB-231, TBRILSCYt+pCDNA3.12e0 *** p<0.0001 vs

\section{c}

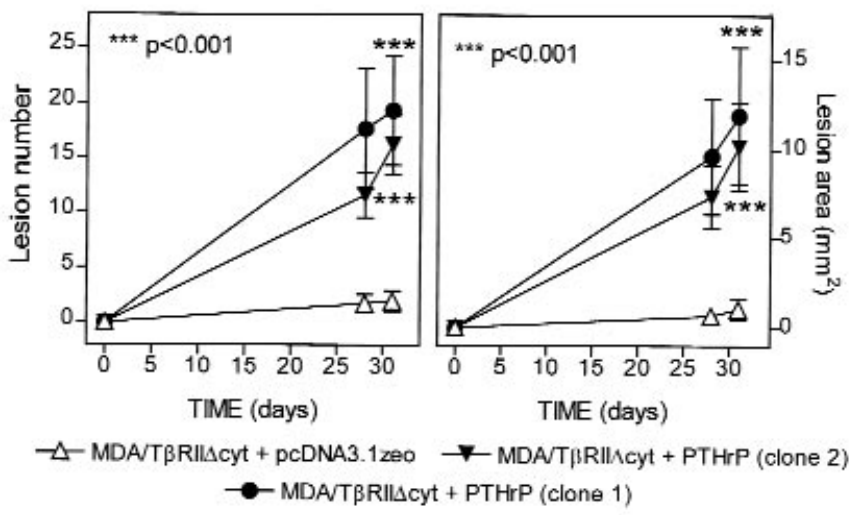

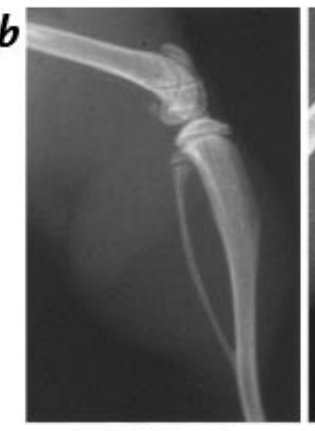

T $\beta$ RII $\Delta$ cyt

$+$

pcDNA3.1zeo

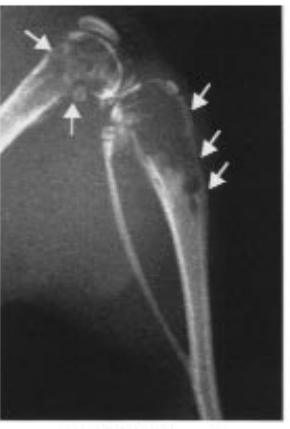

T $\beta$ RII $\Delta$ cyt

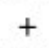

PTHrP(clone1)

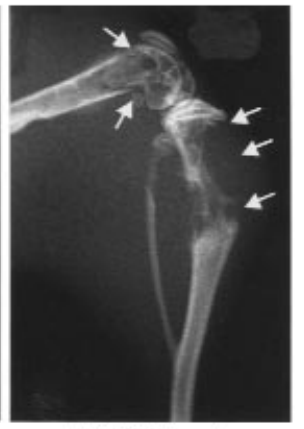

T $\beta$ RII $\Delta$ cyt

$+$

PTHrP(clone2)

$d$

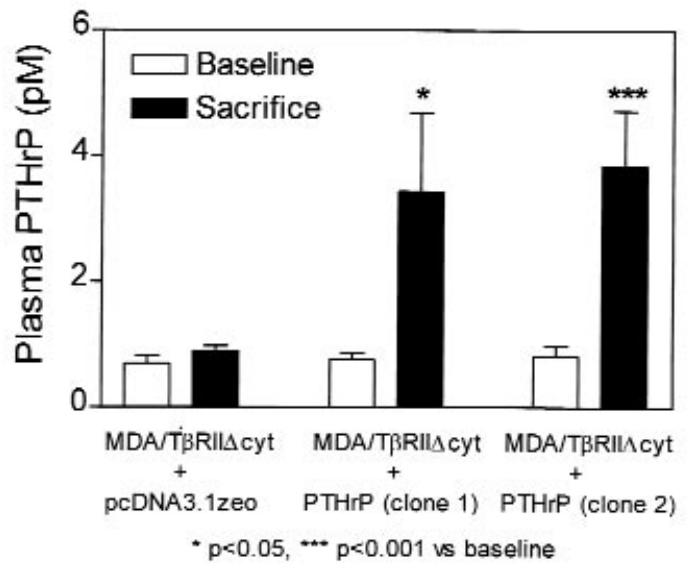

Figure 8

(a) Effect of TGF- $\beta$ on PTHrP secretion by MDA-MB-231 and MDA/T $\beta$ RII $\Delta$ cyt cell clones that overexpress PTHrP (T $\beta R / I \Delta c y t+P T H r P$; two clones) or the empty vector $(T \beta R / I \Delta c y t+p c D N A 3.1 z e o)$. Respective cells were plated onto 48-well plates and treated as in Fig. $1 a$. Values represent the mean $\pm \operatorname{SEM}(n=3$ per group). (b) Representative radiographs of hindlimbs from mice bearing two different T $\beta$ RII $\Delta$ cyt + PTHrP clones or T $\beta R I I \Delta c y t+$ pcDNA3.1zeo control 31 days after tumor inoculation. Osteolytic lesions are indicated by the arrows. (c) Osteolytic lesion number and area on radiographs as measured by computerized image analysis of forelimbs and hindlimbs. Respective tumor cells were inoculated on day 0 . Values represent the mean \pm SEM $(n=5)$ per group. (d) Plasma PTHrP concentrations at sacrifice were significantly higher than respective concentrations prior to tumor inoculation (baseline) in mice bearing either T $\beta R I I \Delta c y t+$ PTHrP tumors. There was no significant difference between baseline and sacrifice values in mice bearing the control T $\beta R I I \Delta c y t+p c D N A 3.1 z e o$ tumors.

calcemia, and nerve compression syndromes. The data presented here suggest a central role for TGF- $\beta$ in the pathogenesis of breast cancer metastasis to bone. Breast cancer cells that metastasizes to bone stimulate osteoclastic bone resorption $(5-7,29)$ and release of active TGF- $\beta$ into the bone microenvironment (4). This increase in locally active TGF- $\beta$ alters tumor-cell behavior to promote growth and bone destruction at the metastatic site. Thus, in the situation of breast cancer metastases to bone, it appears that host-derived TGF- $\beta$ acts on the tumor cells, via a receptor-mediated mechanism, to endow metastatic capacity rather than a case of tumor-derived TGF- $\beta$ acting on the mesenchyme to favor invasion. In the results reported here, TGF- $\beta$ has the paradoxical effect of enhancing metastasis and bone destruction while inhibiting tumor-cell growth in vitro.

Dominant-negative blockade of the type II TGF- $\beta$ receptor had no effect on cell growth in vitro in the absence of TGF- $\beta$ or on cell growth of tumor cells inoculated intramuscularly, but it significantly decreased tumor growth in bone. In contrast, expression of the dominant-negative type II TGF- $\beta$ receptor blocked the growth inhibitory effects of TGF- $\beta$ in vitro. On the basis of the growth results in vitro, one might expect the MDA/T $\beta$ RII $\Delta$ cyt cells to grow more rapidly in bone, when, in fact, these cells had a much slower growth rate in bone compared with the controls.

It has been suggested that breast cancer cells may progress from a growth-inhibited to a growth-stimulated response to TGF- $\beta$ (30). Previous work in breast cancer has focused on the growth inhibitory effects of TGF- $\beta$, as exemplified by the findings that TGF- $\beta 1$ suppresses mammary tumorigenesis in mouse mammary tumor virus/TGF- $\beta 1$ transgenic mice (31). Furthermore, expression of a type II TGF- $\beta$ receptor in the human breast cancer cell line, MCF-7, diminished tumorigenicity (32), whereas transgenic mice overexpressing a dominant-negative mutant type II TGF- $\beta$ receptor had enhanced tumorigenesis in the mammary gland and lung in response to the carcinogen 7,12-dimethylbenz-[a]- 
anthracene (33). The data presented here, however, suggest that the effects of TGF- $\beta$ unrelated to growth inhibition in the context of tumor-host interaction can negatively affect the host. This paradigm goes against the simple idea that losing responsiveness to TGF- $\beta$ is universally permissive for transformation. In fact, the results suggest that maintenance of TGF- $\beta$ receptors on the tumor cells can adversely affect the host by an indirect effect on the metastatic process.

Although loss of TGF- $\beta$ receptor function (34) or its signaling molecules (35-38) has been associated with malignant progression (28), there is growing evidence that TGF- $\beta$ may enhance tumor growth and invasion. In a transgenic mouse model in which TGF- $\beta 1$ expression was targeted to keratinocytes, TGF- $\beta 1$ had a biphasic action during skin carcinogenesis by acting early as a tumor suppressor and later by enhancing a malignant phenotype (39). TGF- $\beta$ has also been shown to induce an epithelial-mesenchymal transdifferentiation to an invasive phenotype $(40,41)$. Mammary epithelial cells transformed by Ras can become resistant to growth inhibition by TGF- $\beta$ (42). Furthermore, in these cells, TGF- $\beta$ enhances invasion and tumorigenesis by inducing a highly motile fibroblastoid phenotype. A possible basis for this is the ability of Ras-activated Erk to phosphorylate and inhibit Smad proteins (43). An oncogenic Ras mutation has been reported in MDA-MB-231 breast cancer cells (44). This may explain why these cells are only moderately growth-inhibited by TGF- $\beta$ in vitro, as well as why cells expressing the constitutively active type I TGF- $\beta$ receptor develop severe bone metastases, a phenotype that indicates excessive tumor growth in bone.

The effects of TGF- $\beta$ in cancer may be tissue-specific. In recent work by Böttinger et al. (45), targeted expression of a dominant-negative type II TGF- $\beta$ receptor in pancreas and liver resulted in pancreatic carcinoma without liver abnormalities. The results presented here are also consistent with a tissue-specific role of TGF- $\beta$ in malignancy. In the situation of breast cancer metastasis to bone, TGF- $\beta$, released and activated as a result of tumor-stimulated osteoclastic bone resorption, is an important segment of a paracrine loop that may be responsible for the affinity with which breast cancer grows in bone. In tumor cells with oncogenic Ras mutations, TGF- $\beta$ may promote further tumor development. The data presented here also suggest the possibility that PTHrP may be an effector of TGF- $\beta$ in bone metastases, because overexpression of PTHrP into the breast cancer cells that expressed the dominant-negative TGF- $\beta$ type II receptor resulted in accelerated bone metastases. The effect of TGF- $\beta$ on tumor cells to stimulate PTHrP may result in adverse effects only when tumor cells are housed in bone rather than in soft tissue sites. Tumor cells in the bone microenvironment produce PTHrP and stimulate osteoclastic bone resorption, which in turn results in the release of active TGF- $\beta$. TGF- $\beta$ then acts on the tumor cells to endow them with metastatic capacity and the ability to stimulate production of PTHrP. The net result is tumor growth, bone destruction, fracture, and the complications of osteolytic bone metastases.

\section{Acknowledgments}

The authors thank Yong Cui and Suzanne D. Taylor for technical assistance, and Kohei Miyazano for antiserum against the human TGF- $\beta$ type II receptor. This work was supported by National Institutes of Health grants AR01899 and CA69158 (to T.A. Guise), CA40035 and AR28149 (to G.R. Mundy), a National Cancer Institute Breast Cancer Spore grant (to J. Massagué), and a San Antonio Cancer Institute grant (to T.A. Guise). J.M. Chirgwin is a Veterans Administration Associate Research Career Scientist. J. Massagué is a Howard Hughes Medical Investigator.

1. Paget, S. 1889. The distribution of secondary growths in cancer of the breast. Lancet. 1:571-572.

2. Coleman, R.E., and Rubens, R.D. 1987. The clinical course of bone metastases from breast cancer. Br. J. Cancer. 55:61-66.

3. Hauschka, P.V., Mavrakos, A.E., Iafrati, M.D., Doleman, S.E., and Klagsbrun, M. 1986. Growth factors in bone matrix. J. Biol. Chem. 261:12665-12674.

4. Pfeilschifter, J., and Mundy, G.R. 1987. Modulation of transforming growth factor $\beta$ activity in bone cultures by osteotrophic hormones. Proc. Natl. Acad. Sci. USA. 84:2024-2028.

5. Boyde, A., Maconnachie, E., Reid, S.A., Delling, G., and Mundy, G.R. 1986. Scanning electron microscopy in bone pathology: review of methods. Potential and applications. Scanning Electron Microsc. 4:1537-1554.

6. Hortobagyi, G.N., et al. 1996. Efficacy of pamidronate in reducing skeletal complications in patients with breast cancer and lytic bone metastases. N. Engl. J. Med. 335:1785-1791.

7. Diel, I.J., et al. 1998. Reduction in new metastases in breast cancer with adjuvant clodronate treatment. N. Engl. J. Med. 339:357-363.

8. Burtis, W.J., et al. 1987. Identification of a novel 17,000-dalton parathyroid hormone-like adenylate cyclase-stimulating protein from a tumor associated with humoral hypercalcemia of malignancy. J. Biol. Chem. 262:7151-7156

9. Moseley, J.M., et al. 1987. Parathyroid hormone-related protein purified from a human lung cancer cell line. Proc. Natl. Acad. Sci. USA. 84:5048-5052.

10. Strewler, G.J., et al. 1987. Parathyroid hormone-like protein from human renal carcinoma cells structural and functional homology with parathyroid hormone. J. Clin. Invest. 80:1803-1807.

11. Jüppner, H., et al. 1991. A G protein-linked receptor for parathyroid hormone and parathyroid hormone-related peptide. Science. 254:1024-1026.

12. Abou-Samra, A., et al. 1992. Expression cloning of a common receptor for parathyroid hormone and parathyroid hormone-related peptide from rat osteoblast-like cells: a single receptor stimulates intracellular accumulation of both cAMP and inositol triphosphates and increases intracellular free calcium. Proc. Natl. Acad. Sci. USA. 89:2732-2736.

13. Burtis, W.J., et al. 1990. Immunochemical characterization of circulating parathyroid hormone-related protein in patients with humoral hypercalcemia of cancer. N. Engl. J. Med. 322:1106-1112.

14. Bundred, N.J., et al. 1991. Parathyroid hormone related protein and hypercalcaemia in breast cancer. Br. Med. J. 303:1506-1509.

15. Powell, G.J., et al. 1991. Localization of parathyroid hormone-related protein in breast cancer metastasis: increased incidence in bone compared with other sites. Cancer Res. 51:3059-3061.

16. Southby, J., et al. 1990. Immunohistochemical localization of parathyroid hormone-related protein in breast cancer. Cancer Res. 50:7710-7716.

17. Guise, T.A., et al. 1996. Evidence for a causal role of parathyroid hormone-related protein in breast cancer-mediated osteolysis. J. Clin. Invest. 98:1544-1548.

18. Zakalik, D., Diep, D., Hooks, M.A., Nissenson, R.A., and Strewler, G.J. 1992. Transforming growth factor $\beta$ increases stability of parathyroid hormone-related protein messenger RNA. J. Bone Miner. Res. 7:104A, S118.

19. Kiriyama, T., et al. 1992. Transforming growth factor $\beta$ stimulation of parathyroid hormone-related protein (PTHrP): a paracrine regulator? Mol. Cell. Endocrinol. 92:55-62.

20. Merryman, J.I., DeWille, J.W., Werkmeister, J.R., Capen, C.C., and Rosol, T.J. 1994. Effects of transforming growth factor- $\beta$ on parathyroid hormone-related protein production and ribonucleic acid expression by a squamous carcinoma cell line in vitro. Endocrinology. 134:2424-2430.

21. Southby, J., Murphy, L.M., Martin, T.J., and Gillespie, M.T. 1996. Cellspecific and regulator-induced promoter usage and messenger ribonucleic acid splicing for parathyroid hormone-related protein. Endocrinology. 137:1349-1357.

22. Cailleau, R., Yong, R., Olive, M., and Reeves, W.J. 1974. Breast tumor cell lines from pleural effusions. J. Natl. Cancer Inst. 53:661-674.

23. Wieser, R., Attisano, L., Wrana, J.L., and J. Massagué. 1993. Signaling activity of transforming growth factor $\beta$ type II receptors lacking specific domains in the cytoplasmic region. Mol. Cell. Biol. 13:7239-7247.

24. Wieser, R., Wrana, J.L., and Massagué, J. 1995. GS domain mutations that constitutively activate $\mathrm{T}$ beta R-I, the downstream signaling com- 
ponent in the TGF-beta receptor complex. EMBOJ. 14:2199-2208.

25. Cárcamo, J., et al. 1994. Type I receptors specify growth-inhibitory and transcriptional responses to transforming growth factor $\beta$ and activin. Mol. Cell. Biol. 14:3810-3821.

26. Guise, T.A., Chirgwin, J.M., Favarato, G., Boyce, B.F., and Mundy, G.R. 1992. Chinese hamster ovarian cells transfected with human parathyroid hormone-related protein cDNA cause hypercalcemia in nude mice. Lab. Invest. 67:477-485.

27. Pandian, M.R., Morgan, C.H., Carlton, E., and Segre, G.V. 1992. Modified immunoradiometric assay of parathyroid hormone-related protein: clinical application in the differential diagnosis of hypercalcemia. Clin. Chem. 38:282-288.

28. Massagué, J. 1998. TGF- $\beta$ signal transduction. Annu. Rev. Biochem. 67:753-791.

29. Sasaki, A., et al. 1995. The bisphosphonate risedronate reduces metastatic human breast cancer burden in bone in nude mice. Cancer Res. 55:3551-3557.

30. Arteaga, C.L., Dugger, T.C., and Hurd, S.D. 1996. The multifunctiona role of transforming growth factor (TGF)- $\beta$ s on mammary epithelial cell biology. Breast Cancer Res. Treat. 38:49-56.

31. Pierce, D.F., Jr., et al. 1995. Mammary tumor suppression by transforming growth factor $\beta 1$ transgene expression. Proc. Natl. Acad. Sci. USA 92:4254-4258.

32. Sun, L., et al. 1994. Expression of transforming growth factor $\beta$ type II receptor leads to reduced malignancy in human breast cancer MCF-7 cells. J. Biol. Chem. 269:26449-26455.

33. Böttinger, E.P., Jakubczak, J.L., Haines, D.C., Bagnall, K., and Wakefield, L.M. 1997. Transgenic mice overexpressing a dominant-negative mutant type II transforming growth factor $\beta$ receptor show enhanced tumorigenesis in the mammary gland and lung in response to the carcinogen 7,12-dimethylbenz-[a]-anthracene. Cancer Res. 57:5564-5569.

34. Markowitz, S., et al. 1995. Inactivation of the type II TGF- $\beta$ receptor in colon cancer cells with microsatellite instability. Science. 268:1336-1338.
35. Eppert, K., et al. 1996. MADR2 maps to $18 \mathrm{q} 12$ and encodes a TGFß-regulated MAD-related protein that is functionally mutated in colorectal carcinoma. Cell. 88:543-552.

36.Zhu, Y., Richardson, J.A., Parada, L.F., and Graff, J.M. 1998. Smad3 mutant mice develop metastatic colorectal cancer. Cell. 94:703-714.

37. Hahn, S.A., et al. 1996. DPC4, a candidate tumor suppressor gene at human chromosome 18q21.1. Science. 271:259-253.

38. Takaku, K., et al. 1998. Intestinal tumorigenesis in compound mutant mice of both Dpc4 (Smad4) and Apc genes. Cell. 92:645-656.

39. Cui, W.E., et al. 1996. TGF $\beta 1$ inhibits the formation of benign skin tumors, but enhances progression to invasive spindle carcinomas in transgenic mice. Cell. 86:531-542.

40. Caulin, C., Scholl, S.G., Frontelo, P., Gamallo, C., and Quintanilla, M. 1995. Chronic exposure of cultured transfected mouse epidermal cells to TGF $\beta 1$ induces an epithelial-mesenchymal transdifferentiation and a spindle tumoral phenotype. Cell Growth Differ. 6:1027-1035.

41. Miettinen, P.J., Ebner, R., Lopez, A.R., and Derynck, R. 1994. TGF- $\beta$ induced transdifferentiation of mammary epithelial cells to mesenchymal cells: involvement of type I receptors. J. Cell Biol. 127:2021-2036

42. Oft, M., et al. 1996. TGF- $\beta 1$ and Ha-Ras collaborate in modulating the phenotypic plasticity and invasiveness of epithelial tumor cells. Genes Dev. 10:2462-2477.

43. Kretzschmar, M., Doody, J., and Massagué, J. 1997. Opposing BMP and EGF signalling pathways converge on the TGF- $\beta$ family mediator Smad1. Nature. 389:618-622.

44. Sepp-Lorenzino, L., et al. 1995. A peptidomimetic inhibitor of farnesyl:protein transferase blocks the anchorage-dependent and -independent growth of human tumor cell lines. Cancer Res. 55:5302-5309.

45. Böttinger, E.P., et al. 1997. Expression of a dominant-negative mutant TGF- $\beta$ type II receptor in transgenic mice reveals essential roles for TGF$\beta$ in regulation of growth and differentiation in the exocrine pancreas. EMBO J. 16:2621-2633. 